
\title{
THE EFFECT OF DIFFERENT LEVELS OF DRY SEASON SUPPLEMENTARY
FEEDING ON THE REPRODUCTIVE PERFORMANCE OF YANKASA SHEEP IN A TWICE-YEARLY LAMBING PROGRAMME
}

\author{
By \\ O. A. OSINOWO, MS. DOMA, N.PATHIRAJA AND V. BUVANENDRAN \\ National A nimal Production Research Institute, \\ Ahmadu Bello University, P.MB. 1096, \\ Zaria, Nigeria.
}

(Received 14 January 1987; accepted for publication 11 February, 1988).

\begin{abstract}
Ninety-four pregnant Yankasa ewes were divided into 3 groups and fed;(1) 0, (2) 200 or (3) $400 \mathrm{~g} / \mathrm{head} / \mathrm{dat}$ of a concentrate supplement in addition to $6 \mathrm{~h}$ grazing daily, from $35.9 \pm 2.0$ days before, to $98,1 \pm 2.0$ days after lambing in the dry season between 2 January and 15 May 1984 in Zaria, Northern Nigeria.

There were no significant differences $(P>0.05)$ bet deen groups in litter size and adjusted birth weight in the initial lambing $35.9 \pm 2.0$ days into the experiment although the latter showed consistent increase with level of supplementation. Adjusted 90 - day weaning weights increased significantly $(P<0.05)$ with each increase in level of supplementation: $5: 5,7.1$ and $8.6 \mathrm{~kg}$ for groups 1,2 and 3 respectively. Correspondingly, the percentage of lambs weaned increased $(48.6,56.4$ and $90.7 \%)$ while ewe mortality declined $(12.9,10.0$ and $3.0 \%)$ with increasing level of supplementation.

The percentage of ewes exhibiting oestrus within $98.1 \pm 2.0$ days post-partum increased with level of supplementation: $77.8,91.3$ and $96.8 \%$ for groups 1,2 and 3 respectively. However, of the ewes showing oestrus, there were no significant differences between groups in post-partum intervals to oestrus and conception. Litter size from matings during the experiment showed non-significant increase with level of supplementation.

It is concluded that dry season supplementary feeding is essential for optimum reproductive performance of Yankasa sheep in a twice-yearly lambing programme.
\end{abstract}

(Key Words: Levels, Dry Season, Supplementary, Feeding, Yankasa, Sheep).

\section{INTRODUCTION}

The effects of undernourishment during late gestation and the early post-partum period in sheep can be grouped into two, namely: those on the ewe and those on the lamb. The latter are manifested as reduced birth weight (Russel, Doney and Reid, 1967, Russel, Maxwell, Sibbald and McDonald, 1977, Adu and Olaloku, 1979), retarded pre-weaning growth 
(Peart, 1967) and increased pre-weaning mortality. Undernourishment in the ewe during late gestation results in reduction in liveweight and loss of body condition with higher incidence of pregnancy toxaemia especially in twincarrying ewes. During the post-partum period, lactation is depressed, more ew es remain anoestrous for prolonged periods while ovulation rate declines and incidence of embryonic mortality may increase, leading to lower litter size in the subsequent lambing (Smith, 1964, Gunn, Doney and Russe1, 1969, 1972, Guerra, Thwaites and Edey, 1972).

In flocks where ewes are lambed once a year, manifestations of undernourishment may not be so severe due to the longer inter-lambing period and freer choice of an optimum lambing season, which usually coincides with period of good pasture growth. However, in twiceyearly lambing flocks, there is a greater probability of one lambing period falling in a fodder-deficient season, for instance the dry season in much of W est Africa. In the absence of seasonal anoestrus in tropical sheep, dry season nutrition is likely to be the most important single factor affecting the biological efficiency (Large, 1970) of twice-yearly lambing production systems in the region.

The present study was designed to study the effects of different levels of dry season supplementary feeding on lamb birth weight and weaning-performance, ewe liveweight and body condition, post-partum oestrus and interval to conception, lambing rate and litter size in a twice-yearly lambing Yankasa flock.

\section{MATERIALS AND METHODS}

The experiment was carried out at the National Animal Production Research
Institut, Shika, Nigeria, latitude $11^{\circ} 12^{\prime} \mathrm{\Lambda}$, longitude $7^{\circ} 33^{\prime} \mathrm{E}$ and $610 \mathrm{~m}$ altitude, within the Northern Guinea Savanna vegetation zone. Mean annual rainfall and temperature recorded at Samaru, $10 \mathrm{~km}$ from Shika are 1107 $\mathrm{mm}$ and $24.4^{\circ} \mathrm{C}$ respectively. The rainy season extends from May to September during which $94 \%$ of the annual rainfall is recorded while the dry season lasts from October to April (Kowal and Knabe, 1972).

The Yankasa flock used in this experiment has been previously described (Osinowo, 1982, Osinowo and Ekpe, 1985) and has been on an accelerated lambing programme with twice-yearly lambing since 1982. A total of 94 pregnant ewes aged 2 to 7 years was involved with the present study. Prior to this experiment, the ewes were grazed on improved pastures for $6 \mathrm{~h}$ daily and fed a $75 \%$ maize: $25 \%$ cottonseed cake concentrate supplement at the rate of $300 \mathrm{~g} / \mathrm{head} /$ day. Water and mineral salt licks were supplied ad libitum. Deworming and tick-baths were carried out routinely. The last lambings of the ewes were between June and August 1983 and they were rebred between July and September 1983 in readiness for the present experiment.

The experiment started on 2 nd January 1984 with the random allocation of the 94 pregnant ewes to 3 treatment groups The experimental treatments were 3 levels of supplementary feeding $(0,200$ and $400 \mathrm{~g} /$ head/ day for Groups 1, 2 and 3 ewes respectively) in addition to $6 \mathrm{~h}$ grazing. The supplementary feed was a concentrate mixture consisting of $75 \%$ maize and $25 \%$ cottonseed cake.

There were 31,30 and 33 ewes in Groups 1, 2 and 3 respectively. The feeding treatment lasted for 134 days, ending on 15 May 1984 when all ewes 
Table 1.

\section{EFFECT OF LEVEL OF DRY SEASON SUPPLEMENTARY FEEDING ON EWE AND LAMB LOSSES TO WEANING IN YANKASA SHEEP}

\begin{tabular}{|c|c|c|c|c|}
\hline \multirow[b]{2}{*}{ Item } & \multicolumn{3}{|c|}{$\begin{array}{l}\text { Level of Supplementary feeding } \\
\qquad \text { (g/ewe/ewe/day) }\end{array}$} & \multirow[b]{2}{*}{ Total } \\
\hline & $\begin{array}{l}\text { Group } 1 \\
0\end{array}$ & $\begin{array}{l}\text { Group } 2 \\
200\end{array}$ & $\begin{array}{l}\text { Group } 3 \\
400\end{array}$ & \\
\hline \multicolumn{5}{|c|}{ Number of pregnant ewes: } \\
\hline Intitially & 31 & 30 & 33 & 94 \\
\hline $\operatorname{Died}^{*}$ & 11 & 0 & 0 & 1 \\
\hline Aborted $d^{* *}$ & 1 & 0 & 0 & 1 \\
\hline Lambed & 29 & 30 & 33 & 92 \\
\hline \multicolumn{5}{|l|}{ Number of lambs: } \\
\hline Born & 37 & 39 & 43 & 119 \\
\hline Stillborn & 0 & 2 & $1 *$ & 3 \\
\hline Weaned & 18 & 22 & 39 & 79 \\
\hline Died & 19 & 17 & 4 & 40 \\
\hline Percent lambs weaned & 48.6 & 56.4 & 90.7 & 66.4 \\
\hline \multicolumn{5}{|c|}{ Number of lambs weaned: } \\
\hline Per ewe mated & 0.58 & 0.73 & 1.18 & 0.84 \\
\hline Per ewe lambed & 0.62 & 0.73 & 1.18 & 0.86 \\
\hline Ewe dea ths to weaning & 4 & 3 & 1 & 8 \\
\hline Percent ewe deaths & 12.9 & 10.0 & 3.0 & 8.5 \\
\hline
\end{tabular}

were placed back on $300 \mathrm{~s} / \mathrm{head} /$ day concentrate supplement. The mean auration $( \pm$ s.e.m) of the feeding treat ment was $35.9 \pm 2.0$ days before lambing and $98.1 \pm 2.0$ days after lambing (Table 2). The lambs were allowed to remain with their dams until weanes at about 3 montlis of age at the end of the feedins treatment.
Oestrus detection commenced in ewes from 2 days after lambing, initially using 2 vasectomized rams but later using 2 intact rams in addition as the number of ewes lambing increased, with care taken to prevent mating by the intact rams through quick intervention. Ewes were checked for oestrus twice daily from $0900-1000 \mathrm{~h}$ and 
Table 2.

\section{EFFECT OF LEVEL OF DRY SEASON SUPPLEMENTARY FEEDING ON BIRTHWEIGHT, WEANING WEIGHT, LIVE- WEIGHT AND BODY CONDITION IN YANKASA SHEEP.}

\begin{tabular}{|c|c|c|c|c|}
\hline \multirow[b]{2}{*}{ Item } & \multicolumn{4}{|c|}{ Level of supplementary feeding (g/ewe/day) } \\
\hline & $\begin{array}{l}\text { Group } 1 \\
0\end{array}$ & $\begin{array}{c}\text { Group } 2 \\
200\end{array}$ & $\begin{array}{l}\text { Group } 3 \\
400\end{array}$ & Total \\
\hline No. of ewes available & 27 & 23 & 31 & 81 \\
\hline $\begin{array}{l}\text { Duration of feeding treat- } \\
\text { ment (days) }{ }^{1} \text { : }\end{array}$ & & & & \\
\hline Before lambing & $34.6 \pm 3.2$ & $32.2 \pm 3.2$ & $39.8 \pm 3.6$ & $35.9 \pm 2.0$ \\
\hline After lambing & $99.4 \pm 3.2$ & $101.8 \pm 3.6$ & $94.2 \pm 3.6$ & $98.1 \pm 2.0$ \\
\hline Overall & 134 & 134 & 134 & 134 \\
\hline Litter size & $1.30 \pm 0.09$ & $1.30 \pm 0.10$ & $1.29 \pm 0.08$ & $1.30 \pm 0.05$ \\
\hline $\begin{array}{l}\text { Adjusted birthweight } \\
(\mathrm{kg})^{2}\end{array}$ & $2.04 \pm 0.09$ & $2.27 \pm 0.11$ & $2.31 \pm 0.05$ & $2.14 \pm 0.05$ \\
\hline Ewe liveweight I (kg) ${ }^{4}$ & $25.1 \pm 0.7^{\mathrm{a}}$ & $25.4 \pm 0.6^{\mathrm{a}}$ & $27.8 \pm 0.6^{\mathrm{b}}$ & $26.2 \pm 0.4$ \\
\hline Ewe body condition Score $1^{\mathrm{s}}$ & $1.37 \pm 0.04^{\mathrm{a}}$ & $1.65 \pm 0.05^{\mathrm{b}}$ & $1.87 \pm 0.07^{\mathrm{c}}$ & $1.64 \pm 0.04$ \\
\hline Ewe liveweight II ${ }^{6}$ & $29.3 \pm 0.7$ & $30.2 \pm 0.8$ & $31.1 \pm 0.7$ & $30.2 \pm 0.4$ \\
\hline Ewe body condition Score II ${ }^{7}$ & $1.91 \pm 0.08^{\mathrm{a}}$ & $2.11 \pm 0.09^{\mathrm{a}, \mathrm{b}}$ & $2.18 \pm 0.09^{b}$ & $2.07 \pm 0.05$ \\
\hline
\end{tabular}

$\mathrm{a}, \mathrm{b}, \mathrm{c}_{\mathrm{Group}}$ means $( \pm$ s.e.m.) on the same row with different superscripts differ significantly
$(\mathrm{P}<0.05)$.

${ }^{1}$ Started 2nd January 1984 and ended 15th May, 1984

${ }^{2}$ Least squares means adjusted for age of dam, type of birth and sex

${ }^{3}$ Least squares means adjusted for age of dam, type of birth, sex and corrected to 90 days
of age.

${ }^{4} 114$ th day of treatment

${ }^{5} 113$ th day of treatment

639 days after end of treatment

${ }^{7} 41$ days after end of treatment. 
1700-1800 h. Ewes detected in estrus were exposed to fertile rams in a pen for $48 \mathrm{~h}$. Kams were changed af ter mating $10-15$ ewes. Oestrus detection was terminated on 15 May 1984. The ewes were weighed twice, on the 114 th dav of treatment (23 June, 1984)

The body condition of the ewes (Jefferies, 1961) were also scored twice on 113th day of treatment (24 April, $1984)$ and 41 days after the end of treat ment (25 June, 1984). The body condition scoring covered six grades as follows. 0 -animals emaciated and on the point of death, I - arimals with prominent backbone with virtually no meat around the bones, sharp lumbar processes and thin eye muscles, 2 animals with prominent but smooth backbone, smooth and rounded lumbar processes and having eye muscles with moderate depth and a little fat, 3 - animals with smooth and rounded backbone with smooth, well-coverage, 4 animals with barely detectable backbone, lumbar processes thickly covered by muscle and full eye muscles with thick fat coverage, 5- animals in which the backbone cannot even be felt with firm pressure, with lumbar processes, which cannot be felt because of fat coverage and having full eye muscles with very thick fat coverage which may be flabby. The ideal condition for breeding ewes is body condition score 3 (Jefferies, 1961). The animals were routinely managed until lambing in July -October, 1984.

The data collected included ewe and lamb losses during the experimental period, litter size, lamb birth weight and weaning weight, ewe liveweight and body condition score, post-partum intervals to oestrus and conception, number of oestrous periods per conception, lambing rate and litter size in the three experimental groups. The data were analysed by one-way analysis of variance and treatment means were compared by Duncan's Multiple Range test (Steel and Torrie, 1960).

\section{RESULTS}

The results of this experiment on the effect of dry season supplementary feeding level on reproductive performance of intensively bred Yankasa ewes are presented in Tables 1 to 3 .

Ewe and lamb losses over the 134 day feeding treatment period are presented in Table 1. In general, ewe and lamb deaths were highest for Group 1 animals which received no supplementary feed other than grazing and were lowest for Group 3 animals, which received 400 $\mathrm{g} /$ head/day concentrate "supplement. These losses were only slightly lower for Group 2 animals compared to the control Group 1. Losses due to abortions and stillbirths were low irrespective of treatment group and did not follow any definite pattern.

There was no significant difference $(\mathrm{P}>0.05)$ in litter size between groups for the initial lambing, which occurred on an average of $35.9 \pm 2.0$ days into the experiment. Least squares means of lamb birth weights adjusted for age of dam, sex and type of birth showed a definite trend, increasing with level of supplementation though the differences between groups were not statistically significant $(P>0.05)$. Least squares means of lamb weaning weigh ts adjusted for age of dam, type of birth, sex, and corrected to 90 days of age increased significantly $(\mathrm{P}<0.05)$ with each increase in level of supplementation (Table 2). Ewe liveweight 39 days after the end of treatment and reversion to the routine 
Table 3

\section{EFFECT OF DRY SEASON SUPPLEMETARY FEEDING ON REBREEDING AND LAMBING PERFORMANCE IN YANKASA SHEEP}

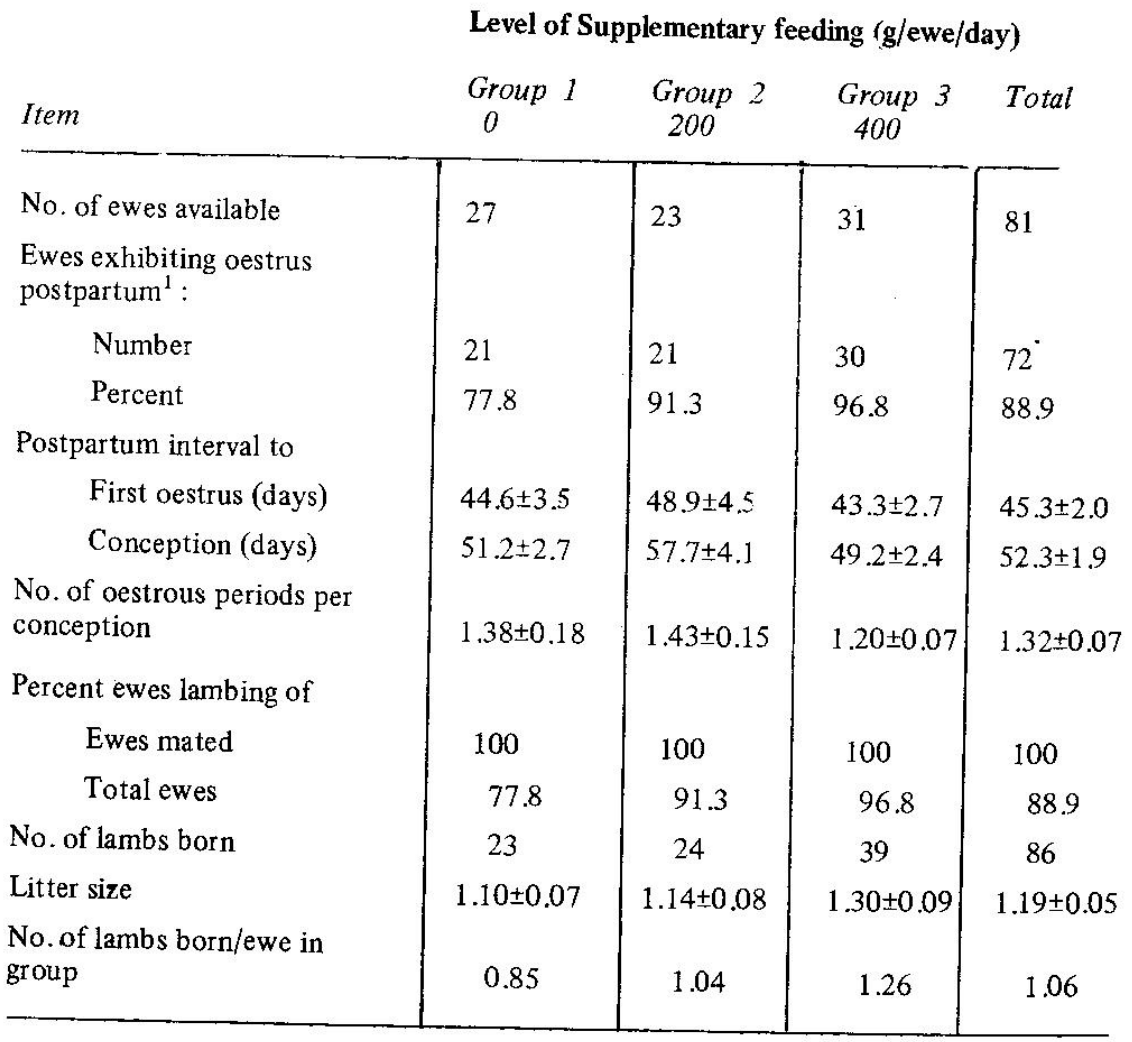

${ }^{1}$ Within an average of 98 days postpartum

supplementary feeding level of 300 $\mathrm{g} /$ head/day were generally higher than before and did not differ significantly $(P>0.05)$ between groups. Similarly, ewe body condition scores 41 days after the end of the treatment were higher than before, though a significant difference $(P<0.05)$ still existed between Groups
1 and 3 ewes. Group 2 ewes did not differ significantly ( $P>0.05)$ from other groups in this respect (Table 2 ).

The proportion of ewes exhibiting at least one oestrus within an average observation period of 98.1 days postpartum increased steadily with increasing level of supplementation from $77.8 \%$ 
for Group 1 ewes to $96.8 \%$ or Group 3 ewes (Table 3). Of the ewes exhibiting oestrus, there were neither definite trewds nor significant differences between groups with regard to the mean post-partum intervals to first oestrus and conception, and number of oestrous periods per conception (Table 3). The litter size realised from the matings during the experiment increased steadily with increasing level of supplementation though the differences were not statistically significant ( $>>0.05$, Table 3$)$.

\section{DISCUSSION}

The present study clearly shows the necessity for dry season supplementary feeding of Yankasa sheep in a twiceyealy lambing programme for optimum reproductive performance. Supplementation of ewes from late gestation resulted in higher lamb birth and weaning weights, and greater proportions of ewes bred within a short interval after lambing. Supplemented ewes also tended to have larger litter sizes than unsupplemented ones

The reduction in lamb mortalities with increasing level of supplementation probably resulted from the greater ability of well-nourished animals to withstand other stresses, especially diseases. The high mortality observed in the unsupplemented group might have been due also to the low birth weights of the lambs. A possitive association between lamb birth weight and survival up to weaning has been reported (Purser and Young, 1959, Khalaf et al., 1979a,b). The trend towards higher birth weights with increasing level of supplementation agrees with previous observations (Russel et al., 1967, 1977, Adu and Olaloku, 1979). The difference in birth weights of $10-15 \%$ in the supplemented groups could be considered in relation to lamb survival and pre-weaning growth rate.

The significant improvement in lamb weaning weights with increasing level of supplementation probably resulted from improved lactation of their dams. However, the growth potential of the lambs might also have been affected by the nutrition of their dams during late pregnancy, which was reflected in the lamb birth weights (Peart, 1967). Also, since the lambs were not separated from their dams during supplementary feeding, the differences in weaning weights may be partly accounted for by the differential access of lambs to the supplementary feed.

The significant differences in ewe liveweights and body condition scores obtained about 113-114th day of the experiment were probably nutritionally induced, particularly as they had largely diappeared $39-41$ days after reversion to routine supplementary concentrate feeding of $300 \mathrm{~g} / \mathrm{ewe} / \mathrm{day}$ at the end of the experiment. The especially poor condition of unsupplemented ewes confirms the inadequacy of the dry season grazing to meet nutritional requirements of pregnant and lactating ewes. In the unsupplemented group, one ewe died of pregnancy toxaemia while poor nutrition may have contributed to other deaths since mortality declined with increasing level of supplementation.

The proportion of ewes showing oestrus within about 98 days post-partum increased with level of supplementation. This confirms earlier observations on nutritionally induced anoestrus (Smith, 1964, Vails Ortiz, 1983). However, of the ewes exhibiting oestrus in this study, the mean post-partum intervals to first oestrus and conception did not differ significantly. This obviously might not have been the case if the ewes had been 
observed for a longer period. It may be difficult to maintain high conception rates within the relatively short re breeding intervals which can be tolerated in a twice yearly lambing programme without supplementation in the dry season in Nigeria.

The similarity in litter sizes between groups for the initial lambing which occurred, in this experiment was expected since the three groups were all subjected to similar nutritional treatment during the mating period preceding the experiment. In the lambing following the experimental treaments there was a trend towards larger litter sizes with increasing level of supplementation, which is in agreement with earlier reports (Gunn et al., 1969, 1972).

It may be concluded from this study that the reproductive efficiency of twiceyearly lambing Yankasa ewes, measured as number of lambs weaned per mated, can be significantly improved through dry season supplementary feeding. The economic advantage of such supplementation however remains to be determined

\section{ACKNOWLEDGEMENTS}

The authors wish to thank Messrs D. Tachio, J. Boman, Idi Danmalam and Ali Sule for care of the animals. The permission of the Director, National Animal Production Research Institute, to publish this paper is gratefully acknowledged.

\section{REFERENCES}

ADU I.F. and OLALOKU, E.A. (1979). A note on nutrition during late pregnancy in West African Dwarf sheep. Anim. Prod. 28.: 123- 126.

GUERRA, J.C.. THWAITES, C.J. and EDEY, T.N. (1972). The effects of components of body weight on reproductive efficiency in the Merino ewe. J. Agric. Sci., 78: 245- 249 .

GUNN, R.G., DUNEY, JM. and RUSSEL, A.J.E. (1969). Fertility in Scottish Blackface ewes as influenced by nutrition and body condition at mating. J. Agric. Sci., 73: 289- 294.

GUNN, R.G., DONEY, J.M. and RUSSEL, A.J.F. (1972). Embryo mortality in Scottish Blackface ewes as influenced by body condition at mating and by postmating nutrition. J. Afric. Sci., 79: 19- 25 .

JEFEERIES, B.C. (1961). Body condition scoring and its use in management. Tasmanian J. Agric., 32: 19- 21.

KHALAF, A.M., DOXEY, D.L., BAXTER, J.T., BLACK, W.J.M., FITZSIMONS, J. and FERGUSON, J.A. (1979a). Late pregnancy ewe feeding and lamb performance in early life. I. Pregnancy feeding level and perinatal lamb mortality. Anim. Prod., 29(3): 393-399.

KHALAF, A.M., DOXEY, D.L., BAXTER, J.T., BLACK, W.J.M., FITZSIMONS, $\checkmark$. and FERGUSON, J.A. (1979b). Late pregnancy ewe feeding and lamb perfor. mance in early life. 2. Factors associated with perinatal lamb mortality. Anim. Prod., 29(3): 401- 410.

KOWAL, J.M. and KNABE, D.T. (1972). An agroclimatological atlas of the northes statcs of nigeria. Ahmadu Bello Univer. sity Press, Zaria.

LARGE, R.V. (1970). The biological efficiency of meat production in sheep. Anim. Prod., 12:393 401. 
OSINOWQ, O.A. (1982). Oestrus synchronization, ar tificial insemination and early rebreeding in Yankasa sheep. Nig. J. Anim. Prod., 9(2): 107- 111.

OSINOWO, O.A. and EKPE, G.A. (1985). Post-Partum oestrus and conception in Yankasa sheep. J. Agric. Sci., 104: 253- 255.

PEART, J.N. (1967). The effect of different levels of nutrition during late pregnancy on the subsequent milk procuction of Blackface ewes and on the growth of their lambs. J. Agric. Sci., 68: 365-371.

PURSER, A.F. and YOUNG, G.B. (1959). Lamb survival in two hill flocks. Anim. Prod., 1: 85- 91.

RUSSEL, A.J.F., DONEY, J.M. and REID, R. L. (1967). The use of biochemical parameters in con trolling nutritional state in pregnant ewes, and the effect of undernourishment during pregnancy on lamb birth-weight. J. Agric. Sci., 68,: 351358.

RUSSEL, A.J.F., MAXWELL, T.J., SIBBALD, A.R. and McDONALD, D. (1977). Relationships between energy intake, nutritional state and lamb birth weight in Greyface ewes. J. Agric. Sci., 89: 667.673.

SMITH, I.D. (1964). Postparturient anoestrus in the Peppin Merino in Western Queensland. Aust. Vet. J., 40. 199--201.

STEEL, R.G.D. and TORRIE, J.H. (1960). Principles and procedures of statistics. McGraw-Hill Book Company, New York. VALLS ORTIZ, M. (1983). Frequent lambing of sheep flocks in Spain: Productivity and management consequences. Livestock. Prod. Sci., 10: 49- 58. 